and scan the facing bar. The development of the mechanical pre-cutter has further advanced, and various types of scalloping machines have been investigated for their suitability in handling Leavers' lace. In dyeing Bourdon cord, the affinity of the dye was found to have an important effect on penetration into the core, but the nature of the cord and greasiness of the core also affect the penetration of the dye liquor. No significant advances in the examination of new flame-proofing materials and methods for their suitability for lace were made during the year.

\section{The American Philosophical Society}

Year Book 1963 of the American Philosophical Society includes a brief history of the Society, a list of officers since 1769 , biographical memoirs, among which are those on N. H. D. Bohr, Lyman J. Briggs, Sir Charles Darwin, Sir Richard W. Livingstone, and reports on meetings during the year (Pp. 738. Philadelphia: The American Philosophical Society, 1964). The reports of standing committees include that on research, recording: 240 grants totalling more than 250,000 dollars approved in 1963 from the Penrose Fund; 65 grants totalling 62,000 dollars from the Johnson Fund; awards of four fellowships totalling 29,000 dollars from the Dallas Fund for research in clinical medicine. Besides these lists of grants, the Committee's report includes notes on the progress of investigations by the recipients of grants. The Year Book also includes a list of members, and reports on finance.

\section{Petroleum Consumption in the United Kingdom in 1963}

Compared with 1962, the final figures published by the Petroleum Information Bureau on behalf of the United Kingdom Petroleum Advisory Committee show that the demand for petroleum products in 1963 totalled 55,692,382 tons, an increase of $\mathbf{9 . 4}$ per cent on the previous year (U.K. Petroleum Industry Statistics: Consumption and Refinery Production, 1962 and 1963. Pp. 8. London: Petroleum Information Bureau, 1964). This is exclusive of bunkers for ships engaged in foreign trade. With one exception, white spirit, deliveries into consumption of petroleum products in the United Kingdom record substantial increases. Consumption of motor spirit was up by 5.6 per cent; industrial spirits (including industrial benzole) rose by more than 7,000 tons; white spirit showed a drop of 2,614 tons; demand for kerosine (burning and vaporizing oils) was more than 200,000 tons greater than in 1962; Derv (Diesel engined road vehicle) fuel increased by 8.7 per cent. Total deliveries of black oils (gas/Diesel and fuel oils) rose by 8.5 per cent. Due mainly to substantial increases in consumption by railways, construction industry, domestic appliances, metal industries and more recently the electricity industry, gas/Diesel oil demand rose by 18.1 per cent. Temperature was largely responsible for boosting burning-oil deliveries by 16.9 per cent, having regard to the severe winter conditions in the year under review. For the rest, deliveries of lubricating oils and greases increased by $3 \cdot 7$ per cent, bitumen supplies by $6 \cdot 2$ per cent, liquid gas by 60 per cent, due largely to growing demand by the Gas Boards, the latter authorities also being responsible for a 26 per cent increase in distillate feedstock and a 24 per cent increase in refinery gas offtake. As in recent years, the demand for chemical feedstock, now a major product of the oil industry consequent on the remarkable growth in the field of petrochemicals, rose by 38.9 per cent. Thus the overall picture is one of steadily increasing demand for petroleum products in Britain, a tendency which is world-wide, one likely to persist for many years to come; notwithstanding known petroleum resourees, of which the Middle East would at present appear to possess the lion's share, in this context the intensive exploration activities of the oil companies everywhere are clearly justified.

\section{International Bird Preservation}

THE 1963 annual report of the British Section of the International Council for Bird Preservation again stresses the widespread dangers resulting from the indiscriminate use of pesticides, and tho urgent need for Government control (Pp. 29. London: The International Council for Bird Preservation, c/o British Museum (Natural History), 1964. 3s.). There has been encouraging progross in the campaign against oil pollution of the sea, several more countries, including the United Kingdom, having accepted. the 1962 amendments to the 1954 Convention for the Prevention of Pollution of the Sea by Oil. There have also been additional adherents to the original Convention. The great mortality among birds during the bitter winter of 1962-63 evoked measures for special protection in many European countries, and in Great Britain tho previously legal taking of eggs of cortain common species: was made an offence. The increase in activitios of armed hooligans and the acquisition and use of dangerous. weapons by irresponsible persons is causing much concern, and the British Section is in consultation with the National Farmors' Union about the possibility of introducing further legislation to deal with this problcm. Sweden ratified the International Convention for the Protection of Birds, Paris, 1950, in March 1962, and it is earnestly hoped that the United Kingdom will also take this step.

\section{National Parks in South Australia}

AN illustrated handbook describing national parks and wild-life reserves of Australia has been published by the Commissioner (South Australian National Parks and Wild Life Reserves: An Account of the National Parks and Reserves situated near Adelaide, South Australia. Edited by Bernard C. Cotton. Pp. 160 (16 plates). Adolaide: Government Printer, 1964). All the parks and reserves are within easy reach of Adelaide and the handbook not only describes how they have come into being but also provides considerable detail about the main features of each park and reserve. Plants and animals peculiar to Australia are given special prominence. The handbook also describes the pleasure resorts con. trolled by the Tourist Bureau. Thero are many uscful black-and-white illustrations and some outstanding colour photographs.

\section{The Western Australian Museum}

THE annual report of the Western Australian Museum for 1962-63 records that in the research collections work has continued in modernizing the accommodation ( $\mathrm{Pp}$. 41. 7 plates. Perth: Government Printer, 1963). In particular, the installation in the basement of firerosistant rooms with automatically operating carbondioxide flooding systems for the spirit-preserved and naphthalene-saturated zoological collections has been completed. In research, membors of the staff have continued to make known the results of their work through publication in spocialist journals. Co-operation with other museums and organizations at an international level is becoming more frequent. Modernization of the Museum buildings has continued in the completion of the remodelled entrance hall. The Museum has had no addition to permanent buildings since 1899 and the Museum Board has made a strong appeal to the Government to implement a decision made in 1958 to build an extension to the James Street Building.

\section{New Zealand Earthquakes, 1958-59}

THE network of seismological stations centred on the Seismological Observatory, Wellington, New Zealand, had in 1958 and 1959 seventeen members. These strotched from Apia ( $13^{\circ} 48 \cdot 4^{\prime}$ S., $171^{\circ} 46 \cdot 5^{\prime}$ W. ) in the north to Scott Base $\left(77^{\circ} 51 \cdot 0^{\prime}\right.$ S., $166^{\circ} 48^{\prime}$ E.) in the south. The organization of the instruments fell into two sections. 